\title{
SOCIO-CULTURAL DIMENSIONS OF MODERNITY IN THE CONTEXT OF COGNITIVE PRACTICES
}

\author{
Aita Sakun \\ Doctor of Philosophy, Associate Professor, Head of the Department of Philosophy, \\ Political Science and Ukrainian Studies, \\ Kyiv National University of Technology and Design, Ukraine \\ e-mail: Ayta.s@ukr.net, orcid.org/0000-0003-2340-3366
}

\section{Daryna Chernyak}

Candidate of Sociological Sciences, Associate Professor, Senior Lecturer at the Department of Philosophy, Political Science and Ukrainian Studies, Kyiv National University of Technology and Design, Ukraine e-mail: daryna1804@gmail.com,orcid.org/0000-0002-1515-6070

\section{Summary}

The article highlights the essence of the new reality which is the basis of global transformations of the society and the entire world order. The new social system is in the focus of attention for politicians, sociologists, economists, and philosophers, as previous assessments of the development prospects ("new industrial", "post-industrial", "information", "post-economic" and other societies) have proved to be imperfect from the standpoint of the real course of events. In recent decades, such concepts as "social postmodernism", "new order", and "globalism" have become widespread. But they also require revision and critical rethinking. Due to these circumstances, there is a problem of identifying opportunities and the role of thinking and knowledge in determining the essence and content of modernity. After all, changes in the society and technological innovations require the study of social transformations, which are the driving force and source of energy of modern civilization.

The peculiar feature of modernity is its dynamism, due to which the complexity and unpredictability of social development is created. Today, it acts as a complex self-developing system characterized by openness and exchange of knowledge and information energy. Its problem can be understood through synergetics, since its mental reflections have specified understanding the mechanisms of modern development. It should be borne in mind that when interpreting synergetics as a theoretical description of self-developing systems, they get rid of one-sidedness that arises when the links between the synergetic paradigm and the system approach are not clearly understood. It is in these connections that synergetic ideas about the meanings of knowledge, education, and learning can be incorporated into the modern picture of the world.

Keywords: society, thinking, knowledge, educational environment, global world, science, synergetics.

\section{DOI: https://doi.org/10.23856/3837}

\section{Introduction}

Defining the relevance of each phenomenon of social, cultural, economic, and political life of the society determines its inclusion in the context of "modernity". Multiple approaches to understanding the meaning of the "modernity" concept has led to a lag in social and scientific progress. Modernity is associated with the freedom of an individual, the independence of their 
thinking and their own choice of position, and it activates the process of self-realization of the individual. There is a need to focus on the formation of modern cognitive and educational environment. It is also necessary to identify how knowledge, thinking, and intelligence determine the development of society and its social institutions while implementing the emerging global tasks.

The main purpose of the study is to reveal the essence and prospects of the world of knowledge and information in the cognitive dimensions of modernity, to establish the relationship between socio-cultural realities based on the experience of interpreting innovative thinking. The purpose involves fulfilling the task of exploring the cognitive field of sociosynergetic theories of thinking and knowledge.

The research methods are determined by the task. The semantic dimensions of modernity are considered and the scope of research on the problem of knowledge and reflections of cognitive activity are analyzed by means of the system approach and the principle of objectivity. The interdisciplinary approach allows revealing the specifics of knowledge development in the information world. Methodological approaches to postmodern discourses and a synergetic paradigm that has revealed the meaningful relationship between thinking and cognition are also used in the study.

The study proves that the problem of "modernity" is directly related to modernization, in the context of which, primarily, it appears to be the evolution of forms of thinking and changing its ways and types, which is historically determined. Today, thinking is one of the factors of "non-determinism", which preconditions the productive development of the society and its structures in the implementation of the emerging global tasks.

\section{Thinking as a basis for the development of socio-cultural reality}

Having separated from the whole world through consciousness, a man proved to be capable of spiritual life and mental activity. Every self-aware person strives to go beyond the world. This means not only the boundaries of the macro- and micro-world, which are widened by our ever-growing knowledge, but also the boundaries of the social world limited by space and time, beyond which we cannot cross. The search for new meanings of the world is a phenomenon of rational and moral nature, because a human as a being dissatisfied with themselves, constantly overcomes themselves in the most important challenges of their life. It is awareness (understanding) and active creation as a condition for the generation of meanings which is "being as co-being", "complicity thinking", as "Dasein (design), as the release of things to the place of their completion, as expressing the intentionality of being, and its volitional intonation" (Tulchinskij G.L., 2006: 25). Due to this, we structure the world with our thinking.

In this context, the ability to think productively is an imperative for the evolution of society. It overcomes dangers, solves urgent problems, and, last but not least, opens up new opportunities for the person. In particular, they include the prospects of new life in all its dimensions social, political, cultural, cognitive-scientific, and so on. These opportunities are determined by the fact that due to the activity of thinking, modern society becomes informational, "knowledgeable". Intrinsically, "the exchange of information, its accumulation, record on physical media, transmission in time and space, coding and decoding are possible at all times and in different types of society" (Medushevskij A.N., 2011: 8-9). And definitely it becomes possible under active participation of thinking as a process of activity.

In order to turn the possibilities of knowledge into reality, thinking must improve its methods of obtaining new knowledge. This progress of thinking is associated with the accumulation of cognitive (information) resources. Since subsequent generations have more 
knowledge and information than previous ones, we can state that this process is progressive (linear). Even failures that occur for one reason or another, being recorded in intellectual products, act as a "source and energy for the development of thinking of future generations" (Medushevskij A.N., 2011: 8-9). For each new epoch, which is determined by thinking, it becomes possible to have a "dialogue with time" - the appeal of modern thinkers to historical experience on issues that have become relevant in current situation. Thus, for the full implementation of political and constitutional reforms at the present stage it is extremely important to study the experience of successes and mistakes of their implementation in history and, consequently, to make critical and accurate analysis of relevant sources that capture the dilemma of intellectuals-reformers of the past and information and knowledge factors that determined cognitive decision-making mechanisms. Thus, in manifestation of mental practices, history regains the function of the "teacher of life" which was previously lost (Medushevskij A.N., 2009: 37-38).

It is important to keep in mind that history is a sequence of epochs, each of which has its "own" way of thinking. This method is an impersonal "ruler", although it manifests itself in specific individuals (emperors, leaders, prophets, etc.). The epoch, so to speak, "was inside every great personality, while their actions, of course, formed the illusion of "lessons of history" "repeating" in time. But hardly anyone in the past knew that the true, decisive force of history is "neither the army, nor the economy, but the way of thinking during the era, that is, what was contained inside a man" (Orudzhev Z.M., 2006: 22). Thinking as an expression of aspirations, desires, and hopes, as a conceptual definition of the past, an assessment of the present and an outline of the future becomes the main driving force of history, no matter what economic imperatives interfere with it.

As long as the epoch "revolves" around an individual in the form of external events, military and environmental threats, economic crises, man-made disasters and socio-psychological and psychological pressures, technological successes, and global trends in the world, they naively believe that they oppose the epoch "externally" and can defeat it if they are strong enough. But by "force" they can mean military, economic (including wealth), political, and especially scientific and technical power. This external opposition of the man to the epoch took mostly the form of the struggle among some social groups, which often represented opposing social and political forces of society.

Thus, the historical epoch is a time of domination of a certain way of thinking in the society. The way of thinking begins to change when a new logical category, connection, or idea appears in its structure. This causes a "storm" of discoveries and innovations in culture and society in general, and a "new experience" or a new epoch is formed. Regarding the "new experience", it should be pointed out that experience as such is not identical to knowledge in the process of constructing methods and criteria of evidence (they cannot lead the individual to the opposite conclusions). But empirical experience, of course, is transformed into knowledge as a result of critical examination of information and derivation of scientific formulas. Experience is "the accumulation of certain skills in the process of direct functioning. Knowledge presupposes recording this experience in certain formulas, in certain significant conclusions, which are also subject to verification, meet the criterion of classification and, thus, must be qualified, verified on the basis of historical sources" (Medushevskij A.N., 2011: 9).

In its turn, the analysis of historical sources should be based on the achievements of cognitive-information theory in historical science, which seeks to combine such concepts as information, psychology, and source studies. The essence of this theory is that the basis of our knowledge is information exchange. It can be direct when we pass information from person to person, and indirect. The latter is carried out through the purposeful formation of human 
intellectual products-things (historical sources in the broadest sense), and, thus, is not limited in time and space. So, you can enter the context of another culture through things and cultural monuments by decoding the information embedded in them by the creators. Thus, cognitive information theory provides a new concept of understanding historical sources. It is the science of all human activities and forms of thinking that have been realized in the course of the evolutionarily and globally holistic historical process. Due to this, the purpose of history is to identify new information about the phenomenon of a man capable of thinking, which determines the prospects of a human and mankind in civilization, fate, and ways of survival (Medushevskij A.N., 2011: 7).

Definitely, such experience determines the development of mental reflection, intensifying the growth of art, logic, and science, especially social one. The reason for the great transformations is that the first changes in the way of thinking of the epoch, influencing its structure, play the role of a paradigm that generates new turns of thinking, solving problems that give non-standard (in terms of previous experience) results, discoveries in culture, science, socio-political, economic life, etc.

An essential indicator of the development of modern society is the movement "from centralization to decentralization", which changes politics, business, and culture. The structure of the industrial society required strict centralization of labor, materials, capital, factories, etc. This is because mass industry was organized on the principle of economies of scale; the more products are produced in the same place and in the same way, the cheaper the unit of this product. However, "strong central leadership" leads to the "death of democracy", says D. Neisbit (Neisbit D., 2003: 144). Decentralization forms new centers, and this means more opportunities and choices for individuals. Due to the decentralization of political power, changes can be made locally, which is, in fact, one of the ways to carry them out. Decentralization is an energetic factor in social change and, consequently, a new logic of thinking.

\section{Formation of new thinking in the temporality of cognitive situations}

The need to further develop the problems of modern thinking requires a revision of the traditional theory of thinking and cognition, their nature, status, conceptual apparatus, and possibilities of modification. Modern theory of cognition is understood as a specific, virtually existing phenomenon created by abstract thinking, which is sense-based and has special features. In this capacity, the theory of cognition deals only with ideal entities within knowledge itself, and its abstractions do not capture the "physical" reality. There is a task of rethinking the role and place of a cognizing subject. Therefore, the tradition of cognition should be based on the principle of trust to the subject.

The dominant factor in the new logic of thinking, which affects all spheres of public life, is the transition from "pyramidal" management structures to "network" ones. In the network management structure, the bureaucracy loses its position because its strength is in the "vertical of dependence", which is incompatible with the logic of the network. "In the network structure, according to D. Neisbit, an important equalizing factor is the information itself. Networks are egalitarian not just because all their members are equal. On the contrary, since networks are diagonal and three-dimensional, they attract people of all levels. But in the network, individuals treat each other as equals because what is important for them is the information, a great equalizer. There are three fundamental reasons why networks now emerge as the most important social form: 1) the death of traditional structures; 2) information noise overload; 3 ) the history of hierarchy failures" (Neisbit D., 2003: 282). What is being created today is a "network" style of management and 
thinking. Hierarchical methods, being so effective in the past, are largely ineffective today, primarily because they lack horizontal connections. Further on, more institutions will be organized according to the management system based on a network model, taking into account the lateral and horizontal connections that intersect and have different directions and vectors.

The new trend, which leads to a significant change in society, is related to the problem of changing individual inclinations of people, lifestyles, and cultures. An individual ceases to choose between two, usually opposite trends according to the formula "either-or". This choice does not allow the individual to make independent decisions based on a new, critical attitude and thinking. Therefore, with the destruction of hierarchical structures, the choice of "either-or" was replaced by "the explosion of multiple individual ways of organizing life and its styles. But the main idea of societies of different possibilities has penetrated into other areas: religion, fine arts, music, food, entertainment, and now has formed those cultures, ethnic and racial differences" (Neisbit D., 2003: 328-329), which have emerged today in the world.

The loss of "collectivity" is a fact. "Individuality of an individual" becomes dominant, as a result of which the nature of "collectivity" begins to change. Collectivity, which is characteristic of the era of mass revolutions, wars and industrialism, is a thing of the past in those parts of the world where the way of life and activities of people are changing due to the widespread use of modern technology and the lack of large settlements, cities, etc. The absence of "mass groups" should lead to the development of creative abilities of a man, which cannot be developed under the dominant influence of "collectivity". The information society does not have an urgent need to develop the "collective abilities" essential for mass activities. Processing homogeneous and necessary information is carried out today with the help of technologies. Therefore, having appeared in the reality of the "information world", a person uses technologies for everything that does not require a purely creative approach or special creative efforts. The main activity of a man as an object in the "information world" is "cognitive activity". Meaning, content, and knowledge are forms of information, whereas the information itself is the ideal object. "Knowledge is a transcendent attribute of the cognitive subject, the denotation of which is the cognitive activity (transformation cycle) of the subject. Each act of cognitive activity is a transcendental transition between levels of abstraction" (Meskov V.S., Mamchenko A.A., 2010: 67), and consequently, between new levels of understanding.

It is in such a situation and under such conditions, that the way of thinking of the present is formed. It is inspired by the "spirit" of research, experiment and creation. The first, urgent features of the way of thinking of a new emerging era are the variety and uniqueness of all levels and gradations that separate one pole from another, in other words, the continuity of transitions through each intermediate link as an independent "quantum step".

\section{Conclusions}

The theoretical significance of the study lies in deepening the socio-philosophical meaning of the "modernity" concept, substantiating its semantic dimension in the parameters of science, knowledge, and thinking in the spiritual and intellectual codes of globalization. It is determined that all the factors and causes of modernity are due to the way of thinking. Its creativity, depth of understanding, and dynamics depend on the progress of civilization in general. The starting point is realizing that the empirical level of cognition assimilates logical connections of one type, but as cognitive activity becomes more complex, specific thinking processes are required. They generate increasingly complex forms of theoretical awareness of the world, i.e. philosophy, science, education, and various forms of their presentation, i.e. methodological 
reflections, cognitive discourses, interpretation, synergetics, and communicative approach, due to which the modern era appears in its specific definition and objectivity.

The practical significance of the work is determined by the fact that the main provisions of the study will contribute to the further development of current socio-cultural, cognitive, and axiological problems of modern social philosophy. The research materials can be used for creating teaching and methodological support for such courses as "Philosophy of Science and Research Methodology", "Social Philosophy", "Methodology of Scientific Cognition”.

\section{References}

Bogomolov, A.S. (1982). Dialekticheskiy logos [Dialectic Logos]. Moscow: Mysl. [in Russian] Egorov, D.G. (2006). Esli paradigmy nesoizmerimy, to pochemu oni vse-taki menyayutsya? [If the paradigms are incommensurable, then why are they still changing?]. Voprosy filosofii. Issue 3. [in Russian]

Filosofiya v sovremennoj kulture: novye perspektivy (Materialy «kruglogo stola»). (2004). [Philosophy in modern culture: new perspectives (Materials of the "round table")]. Voprosy filosofii. Issue № 4. [in Russian]

Fromm, E. (1990). Imet ili byt. [To have or to be]. Moscow: Progress. [in Russian]

Hegel, G.W.F. (1977). Filosofiya duha [Philosophy of Soul]. Entsiklopediya filosofskih nauk. Vol. 3. Moscow: Mysl. [in Russian]

Hegel, G.W.F. (1993). Filosofiya istorii. [Philosophy of History]. SPb.: Nauka. [in Russian] Hramova, V.L. (2011). Kulturologicheskie obrazy nauki v postpozitivizme. [Culturological images of science in postpositivism]. Sofiia. Kulturolohichnyi zhurnal. Issue № 11. [in Russian] Jung, C.G. (1997). Soznatelnoe i bessoznatelnoe. [Conscious and unconscious]. SPb.: Aletejya. [in Russian]

Medushevskij, A.N. (2009). Kognitivno-informacionnaya teoriya kak novaya filosofskaya paradigma gumanitarnogo podsoznaniya. [Cognitive information theory as a new philosophical paradigm of the humanitarian subconscious]. Voprosy filosofii. Issue №. 10. [in Russian]

Medushevskij, A.N. (2011). Znanie o proshlom v sovremennoj kulture (materialy kruglogo stola). [Knowledge of the Past in Modern Culture (Round table materials)]. Voprosy filosofii. Issue № 12. [in Russian]

Meskov, V.S., Mamchenko, A.A. (2010). Mir informacii kak trinitarnaya model Universuma. Postneklassicheskaya metodologiya kognitivnoj deyatelnosti. [The World of Information as a Trinitarian Model of the Universum. Postnonclassical Cognitive Methodology]. Voprosy filosofii. Issue № 5. [in Russian]

Nejsbit, D. (2003). Megatrendy. [Megatrends]. Moscow: OOO «Izdatelstvo ACT»: ZAO NPP «Ermak». [in Russian]

Neklessa, A.I. (2001). Transmutaciya istorii. [Transmutation of History]. Voprosy filosofii. Issue № 3. [in Russian]

Orudzhev, Z.M. (2006). Sposob myshleniya epohi i princip apriorizma. [The way of thinking of the era and the principle of a priori]. Voprosy filosofii. Issue № 5. [in Russian]

Orudzhev, Z.M. (2009). Sposob myshleniya epohi: Filosofiya proshlogo. [The way of thinking of the era: the philosophy of the past]. Moscow: Editorial URSS. [in Russian]

Struktura nauchnyh revolyucij. [The Structure of Scientific Revolutions]. Moscow: AST. [in Russian]

Tulchinskij, G.L. (2006). O prirode svobody. [About the nature of freedom]. Voprosy filosofii. Issue № 4. [in Russian] 